\title{
Genotyping of Peach and Nectarine Cultivars with SSR and SRAP Molecular Markers
}

\author{
Riaz Ahmad, Dan Potter, and Stephen M. Southwick ${ }^{1}$ \\ Department of Pomology, University of California, Davis, CA 95616
}

AdDitional Index words. Prunus persica, DNA fingerprinting, cultivar identification

\begin{abstract}
Simple sequence repeat (SSR) and sequence related amplified polymorphism (SRAP) molecular markers were evaluated for detecting intraspecific variation in 38 commercially important peach and nectarine (Prunus persica) cultivars. Out of the 20 SSR primer pairs 17 were previously developed in sweet cherry and three in peach. The number of putative alleles revealed by SSR primer pairs ranged from one to five showing a low level of genetic variability among these cultivars. The average number of alleles per locus was 2.2 . About $76 \%$ of cherry primers produced amplification products in peach and nectarine, showing a congeneric relationship within Prunus species. Only nine cultivars out of the 38 cultivars could be uniquely identified by the SSR markers. For SRAP, the number of fragments produced was highly variable, ranging from 10 to 33 with an average of 21.8 per primer combination. Ten primer combinations resulted in $\mathbf{4 9}$ polymorphic fragments in this closely related set of peaches and nectarines. Thirty out of the 38 peach and nectarine cultivars were identified by unique SRAP fingerprints. UPGMA Cluster analysis based on the SSR and SRAP polymorphic fragments was performed; the relationships inferred are discussed with reference to the pomological characteristics and pedigree of these cultivars. The results indicated that SSR and SRAP markers can be used to distinguish the genetically very close peach and nectarine cultivars as a complement to traditional pomological studies. However, for fingerprinting, SRAP markers appear to be much more effective, quicker and less expensive to develop than are SSR markers.
\end{abstract}

The peach (Prunus persica $\mathrm{L}$ ), native to China, is a member of the stone fruit genus Prunus (Rosaceae), which also includes other commercially important species such as sweet and sour cherries, apricot, plum, and almond. Peach and nectarine have a fast rate of cultivar replacement. Until 1950, chance seedling selection provided most of the peach and nectarine cultivars for the world's production. Cultivars have also arisen from sports in peach or nectarine trees. Since 1990, the intensive peach breeding activity worldwide has released almost 500 commercial cultivars, half of which have been obtained by cross pollination (Fideghelli et al., 1998). Today, both public and private breeding programs have provided most peach and nectarine varieties grown in California resulting in constant changes in the list and ranking of those grown for commercial products. Most commercial cultivars have originated from a few parental cultivars used by the United States breeding programs of the early twentieth century. All this has drastically eroded the genetic variability of this crop (Scorza et al., 1985, 1988). In contrast with other members of Prunus, peach is a self-compatible species and a high level of inbreeding is found (Warburton and Bliss, 1996). According to Testolin et al. (2000), several cultivars with great breeding value show a low degree of heterozygosity. This situation demands a highly reliable and efficient method of cultivar identification.

Classical methods of identification and characterization of cultivars in fruits have mostly relied upon a large set of phenotypic data that is often difficult to assess, may vary with environment and production practices, and can be time consuming to collect when surveying large populations that may be growing in different locations. Molecular markers based on DNA are stable, detectable in all tissues and independent of environmental or

$\overline{\text { Received for }}$ publication 16 Apr. 2003. Accepted for publication 23 Oct. 2003. The cost of publishing this paper was defrayed in part by the payment of page charges. Under postal regulations, this paper therefore must be hereby marked advertisement solely indicate this fact. The authors are thankful to California Fruit Tree Agreement (CTFA) for financial support of this work and providing leaf samples for analyses. We are also thankful to Dr Tom Gradziel and Kitren Glozer for the critical review of the manuscript.

1To whom corresponding should be addressed; e-mail smsouthwick@ucdavis.edu. seasonal conditions. They can be used for cultivar identification, diversity analysis, assessment of parentage, patent issues and quality control of rootstock-seed lots. A variety of molecular techniques have been developed for measuring genetic variability. Of the possible alternatives, isozymes have been shown to be insufficiently variable in peach due to low polymorphism of the species (Arulsekar et al.,1986; Messeguer et al., 1987). Randomly amplified polymorphic DNA (RAPD) markers have also been assayed, (Warburton and Bliss, 1996) but poor reproducibility and low multiplexing output limit their use. Amplified fragment length polymorphism (AFLP) markers have a multiplexing ratio, but their main disadvantage is the complexity and requirement of licensing for commercial use.

One of the most reliable molecular marker systems is microsatellites or simple sequence repeats (SSRs), which are abundant and well distributed throughout the nuclear genomes of eukaryotes. These are mostly present in noncoding DNA, which can accumulate mutations more rapidly than the coding DNA. Simple sequence length polymorphism (SSLP) caused by variation in the number of repeat units, can be easily detected by PCR using pairs of primers designed from unique sequences bordering the SSR motifs. SSRs are generally considered the marker of choice for genetic fingerprinting purposes in fruit trees, due to their high levels of polymorphism, high degree of reliability and reproducibility, and codominant mode of inheritance. In plants, these markers have been used widely for cultivar identification and genetic mapping (Cipriani et al., 1999; Guilford et al., 1997) and are a powerful genetic resource for phylogenetic studies (Provan et al., 1996). Although development of SSR markers is expensive and time consuming, the cross-transportability of microsatellites among species of Prunus (Cipriani et al., 1999; Downey and Iezzoni 2000; Hormaza, 2002; Sosinski et al., 2000) can reduce the development costs. Downey and Iezzoni (2000) used SSR markers identified in other Prunus to study genetic diversity in black cherry (Prunus serotina). Sosinski et al. (2000) developed SSR markers for peach, which were partially usable in apricot (Prunus armeniaca) and sour cherry (Prunus cerasus). 
Another PCR-based molecular marker system, SRAP (Sequenced Related Amplified Polymorphism), preferentially amplifies ORFs (Open Reading Frames) and combines simplicity, reliability, moderate multiplexing ability and facile sequencing of selected bands ( $\mathrm{Li}$ and Quiros, 2001). It targets coding sequences in the genome and results in a moderate number of codominant markers. According to Ferriol et al., (2003), the information given by SRAP markers was more concordant to the morphological variability and to the evolutionary history of the morphotypes than of AFLP markers in Cucurbito pepo germplasm. The protocol was originally developed in Brassica where it provides more markers per gel, but has not been widely used in fruit trees.

Objectives of the present project were to (1) identify and characterize peach and nectarine cultivars with SSR and SRAP markers, (2) test the transferability of SSR markers developed in sweet cherry (Prunus avium L.) for molecular analysis in peach and nectarine (Prunus persica; subgenus Amygdalus), and (3) evaluate the potential use of a new protocol, SRAP, for detecting intraspecific variation among peach and nectarine cultivars.

\section{Materials and Methods}

Plant material and DNA extraction. In the present study we analyzed 21 peach and 17 commercial nectarine cultivars grown in California (Table 1). DNA was extracted from leaves by the CTAB method of Doyle and Doyle (1987) with some modification. A 300- to 400-mg sample was put into a $1.5-\mathrm{mL}$ microcentrifuge tube and crushed into powder under liquid nitrogen. To that tube $500 \mu \mathrm{L}$ preheated extraction buffer $(2 \%$ CTAB, $100 \mathrm{~mm}$ Tris- $\mathrm{HCl}$, $\mathrm{pH} 8.0,1.4 \mathrm{~m} \mathrm{NaCl}, 20 \mathrm{~mm}$ EDTA, $1 \%$ PVP-40 and $10 \mathrm{~mm}$ DTT) was added. Ten microliters proteinase $\mathrm{K}(50 \mu \mathrm{g} / \mathrm{mL})$ was then added and incubated at $65^{\circ} \mathrm{C}$ for $30 \mathrm{~min}$ in a water bath. The tubes were cooled to room temperature and $500 \mu \mathrm{L}$ chloroform: isoamyl alcohol (24:1) was added. The solution was gently mixed

Table 1. Peach and nectarine cultivars tested with SSR and SRAP molecular markers.

\begin{tabular}{|c|c|c|c|}
\hline Cultivar & Pedigree & Origin $^{z}$ & Date \\
\hline Fancy Lady & Sparkle mutation & M\&M & 1989 \\
\hline Brittney Lane & Unknown & CFZ & \\
\hline September Snow & [(Royal Gold x Red Grand op) x White Lady] & CFZ & 1992 \\
\hline Sweet Scarlet & $\left\{\left[\left(\mathrm{O}^{\prime}\right.\right.\right.$ Henry $\mathrm{x}$ Giant Babcock $) \times($ Red Grand op $\left.)\right]$ x Sweet Gem $\left.]\right\}$ & $\mathrm{CFZ}$ & 1996 \\
\hline Snow Giant & $\{($ nect $\times$ Royal Gold) F2 x [O'Henry op x (May Grand op x Sam Houston) $]\}$ & CFZ & 1993 \\
\hline Diamond Princess & (Red Diamond $x$ peach sel) & $\mathrm{B} \& \mathrm{~B}$ & 1989 \\
\hline Autumn Snow & [Zaiger 107ED101(Snow Giant op) x Zaiger 97GF518 (Snow Giant op)] & $\mathrm{CFZ}$ & 1997 \\
\hline Autumn Flame & [A48-70 (unknown) x 1-14s-28 (O’Henry x Fairtime)] & JFD & 1996 \\
\hline September Sun & {$\left[\left(\mathrm{O}^{\prime} H e n r y\right.\right.$ op $)$ op $]$} & TOC & 1987 \\
\hline Earlitreat & $\{$ Zaiger 12ED34 $[=($ Red Grand $\times$ Desertgold $)] \times$ Sweet Gem $\}$ & CFZ & 1997 \\
\hline Crimson Lady & [(Red Diamond $x$ Springcrest $) \times$ selection $]$ & $\mathrm{B} \& \mathrm{~B}$ & 1992 \\
\hline Crown Princess & (Red Diamond $x$ peach selection) & $\mathrm{B} \& \mathrm{~B}$ & 1988 \\
\hline Flavor Crest & $(\mathrm{P} 53-68 \times \mathrm{FV} 89-14)$ & USF & 1974 \\
\hline Rich Lady & (Amparo op) & $\mathrm{CFZ}$ & 1990 \\
\hline Summer Sweet & $\left\{\left[\right.\right.$ sel $x\left(O^{\prime}\right.$ Henry $x$ Giant Babcock $\left.)\right]$ F2 x [(Redwing $x$ nect $\left.) F 2\right]$ & $\mathrm{CFZ}$ & 1992 \\
\hline Elegant Lady & (Early O’Henry x July Lady) & GRM & 1979 \\
\hline Zee Lady & (O’Henry x June Lady) & CFZ & 1986 \\
\hline Sun Lady & $\{$ J.H. Hale x $[($ Maxine x July Elberta $)$ op $]\}$ & GRM & 1966 \\
\hline O’Henry & (Merrill Bonanza op) & GRM & 1970 \\
\hline Ryan Sun & (O’Henry op) & TOC & 1985 \\
\hline Queen Crest & (Maycrest mutation) & BAL & 1986 \\
\hline Diamond Bright & (August Red x Aurora Grand) & $\mathrm{B} \& \mathrm{~B}$ & 1996 \\
\hline Bright Pearl & [(Red Glen x (August Red x Bradcrim) $]$ & $\mathrm{B} \& \mathrm{~B}$ & 1994 \\
\hline Royal Glo & [(dwarf nect x Ruby Gold) op x May Glo] & $\mathrm{CFZ}$ & 1993 \\
\hline Arctic Pride & [(Ruby Gold x Redwing $)$ (O'Henry x Giant Babcook)] & $\mathrm{CFZ}$ & 1993 \\
\hline September Red & [(Red Free $x$ Tom Grand $) \times$ Sparkling Red] & $\mathrm{B} \& \mathrm{~B}$ & 1986 \\
\hline Zee Grand & [(Red Grand x Royal Gold) F3 ] & CFZ & 1991 \\
\hline June Pearl & [(Bradcrim x Diamond Jewel) F2 ] & $\mathrm{B} \& \mathrm{~B}$ & 1995 \\
\hline Fire Pearl & [Red Glen x (August Red x Bradcrim)] & $\mathrm{B} \& \mathrm{~B}$ & 1995 \\
\hline Mayglo & [(Fayette x May Grand)F2 ] & $\mathrm{CFZ}$ & 1984 \\
\hline Rose Diamond & (Early Diamond x dwarf peach) & $\mathrm{B} \& \mathrm{~B}$ & 1990 \\
\hline Arctic Star & (white nect x May Glo) & $\mathrm{CFZ}$ & 1995 \\
\hline Spring Bright & (May Diamond $x$ sel) & $\mathrm{B} \& \mathrm{~B}$ & 1990 \\
\hline Ruby Diamond & (Red Diamond x sel) & $\mathrm{B} \& \mathrm{~B}$ & 1992 \\
\hline Summer Bright & (Red Diamond $x$ peach sel) & $\mathrm{B} \& \mathrm{~B}$ & 1987 \\
\hline Summer Fire & (Red Diamond $x$ peach sel) & $\mathrm{B} \& \mathrm{~B}$ & 1990 \\
\hline Red Jim & (Regal Grand mutation) & JCS & 1980 \\
\hline August Red & [(Red Diamond x Autumn Free) F2] & $\mathrm{B} \& \mathrm{~B}$ & 1988 \\
\hline
\end{tabular}

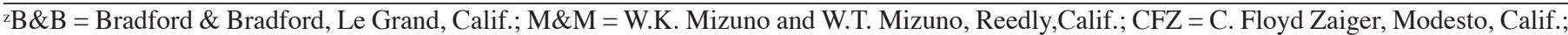
GRM = Grant Merrill, Red Bluff, Calif.; JFD = James F. Doyle, Clovis, Calif.; TOC = Thomas O. Chamberlin, Del Ray, Calif.; USF = U.S. Department of Agriculture, Fresno, Calif.; JCS = James C. Sorenson and James K. Ho, Reedley, Calif.; BAL = Balakian, Reedley, Calif.; Handbook of Peach and Nectarine Varieties. USDA, Agriculture Handbook \# 714. 
and centrifuged at 13,000 rpm for $5 \mathrm{~min}$. The supernatant was transferred to a new tube, 0.6 volume isopropanol was added and mixed gently to precipitate the DNA. The mixture was centrifuged at 13,000 rpm for $5 \mathrm{~min}$, the supernatant was removed and the DNA pellet was washed with $70 \%$ ethanol. The pellet was air dried and resuspended in $100 \mu \mathrm{L}$ of TE buffer. The resulting DNA solution was cleaned by the addition of $1 / 10$ volume $3 \mathrm{M}$ sodium acetate and two volumes of $100 \%$ ethanol, mixed gently and kept at $-20^{\circ} \mathrm{C}$ for $30 \mathrm{~min}$. Next the solution was centrifuged at 13,000 rpm for $15 \mathrm{~min}$, the supernatant removed and the pellet washed with $70 \%$ ethanol, air dried and resuspended in $50 \mu \mathrm{L} \mathrm{TE}$ buffer. DNA quality and quantity was determined by running in ethidium bromide stained $1.0 \%$ agarose gel.

MARKER ANALYSIS. Twenty SSR primer pairs were used, of which seventeen were previously developed in sweet cherry (Struss et al., 2003) and three in peach (Cipriani et al., 1999; Sosinski et al., 2000) (Table 2). The forward primers were labeled with IRD800 and IRD700 to be detected on an automated DNA sequencer (LI-COR, Nebr.). PCR was carried out in a total volume of $12 \mu \mathrm{L}$ using DNA engine tetrad thermal cycler (MJ Research, Inc, Walthan, Mass.) under the following conditions: 20 to $25 \mathrm{ng}$ of template DNA, 250 nmole each primer, $200 \mu \mathrm{mol}$ dNTPs, 1 unit of Taq Polymerase (Qiagen), 1.5 to $2 \mathrm{~mm} \mathrm{MgCl}, 1 \times \mathrm{PCR}$ buffer. The reaction, depending on the primer pair, was run for 35 to 45 cycles (denaturing at $94^{\circ} \mathrm{C}$ for $1 \mathrm{~min}$, annealing at 55 or $60{ }^{\circ} \mathrm{C}$ for $1 \mathrm{~min}$, with a 2 -min extension at $72{ }^{\circ} \mathrm{C}$ ), followed by a single extension at $72{ }^{\circ} \mathrm{C}$ for $10 \mathrm{~min}$. One microliter of reaction products was mixed with 6 $\mu \mathrm{L}$ of formamide dye, denatured at $94{ }^{\circ} \mathrm{C}$ for $3 \mathrm{~min}$, and rapidly cooled on ice for $10 \mathrm{~min}$. Amplified fragments were separated by electrophoresis on 0.25 -mm-thick $5.5 \%$ polyacylamide gels and visualized using a DNA sequencer Gene Readir 4200 (LI-COR). At least two independent PCR reactions were performed for each DNA sample. Gene profiler analysis software (Scanalytics, Fairfax, Va.) was used for measuring allele size. Manual editing of the allele size was performed for more accuracy. Bands were scored as present (1) or absent (0).
To complement the SSR analyses, SRAP markers were tested on the peach and nectarine samples. SRAP is a PCR-based marker system that uses two primers. The first type of primer (forward) is $17 \mathrm{bp}$ long, and contains a fixed sequence of 14 nucleotides rich in $\mathrm{C}$ and $\mathrm{G}$, and three selective bases at the 3 ' end. This primer preferentially amplifies exonic regions, which tend to be rich in these nucleotides. The second type of primer (reverse), with 18 bp, contains a sequence of 15 nucleotides, rich in $\mathrm{A}$ and $\mathrm{T}$, and three selective bases at the $3^{\prime}$ end. This primer preferentially amplifies intronic regions and regions with promoters, rich in these nucleotides. The observed polymorphism fundamentally originates in the variation of the length of these introns, promoters and spacers, both among individuals and among species ( $\mathrm{Li}$ and Quiros, 2001). Initially 20 SRAP primer combinations were tested on two peach and two nectarine cultivars. From those, 10 primer combinations (Me1Em6, Me2Em17, Me2Em19, Me3Em19, Me4Em3, Me4Em4, Me4Em19, Mo1Em6, Mo1Em3, Te1Em18,) were selected because they provided the greatest reproducibility and number of markers per gel. The following primers, with the forward one labeled with IRD800 or IRD700 to be detected in a LI-COR DNA sequencer (Long Readir 4200), were used:

Forward Primers (5'-3'):

Me1: TGAGTCCAAACCGGATA

Me2: TGAGTCCAAACCGGAGC

Me3: TGAGTCCAAACCGGAAT

Me4: TGAGTCCAAACCGGACC

Te1: TGTGTGGTTAATATGAGC

Reverse primers $\left(5^{\prime}-3^{\prime}\right)$ :

Em3: GACTGCGTACGAATTGAC

Em4: GACTGCGTACGAATTTGA

Em6: GACTGCGTACGAATTGCA

Em17:GACTGCGTACGAATTGAG Em18: GACTGCGTACGAATTGCC

Mo1: GCAGACATGGCGACAAT Em19:GACTGCGTACGAATTTCA

At the beginning of the $\mathrm{PCR}$ reaction, the annealing temperature is set at $35^{\circ} \mathrm{C}$ and run for 5 cycles. Then the annealing temperature is raised to $50{ }^{\circ} \mathrm{C}$ for another 35 cycles. Denaturing is done at 94 ${ }^{\circ} \mathrm{C}$ for $1 \mathrm{~min}$ while extension is at $72^{\circ} \mathrm{C}$ for $1 \mathrm{~min}$ in both the first 5 cycle and the last 35 cycle. Two microliter of reaction products were mixed with $6 \mu \mathrm{L}$ of formamide dye, denatured at $94{ }^{\circ} \mathrm{C}$ for $3 \mathrm{~min}$, and rapidly cooled on ice for $10 \mathrm{~min}$. The amplicons were separated by $5.5 \%$ denatured acrylamide gels and detected by a

Table 2. SSR primers, repeat motif, number of alleles and their size range in peach and nectarine cultivars.

\begin{tabular}{|c|c|c|c|c|}
\hline Primers & Sequences 5'-3' & Repeat motif & Alleles & Size (bp) \\
\hline UCD-CH12* & Struss et al., 2003 & $(\mathrm{CA}) 14$ & 2 & $173-175$ \\
\hline UCD-CH13* & Struss et al., 2003 & (CA) 10 & 2 & $143-145$ \\
\hline UCD-CH14* & Struss et al., 2003 & (CT)18 & 5 & $155-185$ \\
\hline UCD-CH15* & Struss et al., 2003 & (CT)15 & 4 & $78-120$ \\
\hline UCD-CH17* & Struss et al., 2003 & $(\mathrm{CT}) 11$ & 1 & 193 \\
\hline UCD-CH19* & Struss et al., 2003 & (CA) 12 & 2 & $128-134$ \\
\hline $\mathrm{UCD}-\mathrm{CH} 21^{*}$ & Struss et al., 2003 & (CA) 18 & 2 & $100-115$ \\
\hline UCD-CH26* & Struss et al., 2003 & (CT)10 & 1 & 140 \\
\hline UCD-CH31* & Struss et al., 2003 & (CT)26 & 2 & $165-167$ \\
\hline UCD-CH36* & Struss et al., 2003 & $(\mathrm{CT}) 13(\mathrm{CA}) 5$ & 2 & $130-134$ \\
\hline UCD-CH39* & Struss et al., 2003 & (CT) 28 & 2 & $135-37$ \\
\hline UCD-CH51* & Struss et al., 2003 & (CT)16 & 2 & $145-354$ \\
\hline UCD-CH24* & Struss et al., 2003 & (CA) 18 & 1 & 94 \\
\hline UCD-CH10* & Struss et al., 2003 & (CA)12 & $\mathrm{N}^{\mathrm{z}}$ & $\mathrm{N}$ \\
\hline UCD-CH11* & Struss et al., 2003 & (CT)15 & $\mathrm{N}$ & $\mathrm{N}$ \\
\hline UCD-CH16* & Struss et al., 2003 & (CT)20(CA)10 & $\mathrm{N}$ & $\mathrm{N}$ \\
\hline UCD-CH18* & Struss et al., 2003 & (CT)23 & $\mathrm{N}$ & $\mathrm{N}$ \\
\hline UDP96-001** & Cipriani et al., 1999 & (CA) 17 & 1 & $120-124$ \\
\hline PCHGMS1** & Sosinski et al., 2000 & (AC)12(AT)6 & 3 & 185-192 \\
\hline PCHGMS-2** & Sosinski et al., 2000 & (CT) 24 & 2 & $165-171$ \\
\hline
\end{tabular}

${ }^{\mathrm{z}} \mathrm{N}=$ Did not amplify in peach and nectarine.

* Primers originated from sweet cherry.

***Primers originated from peaches. 


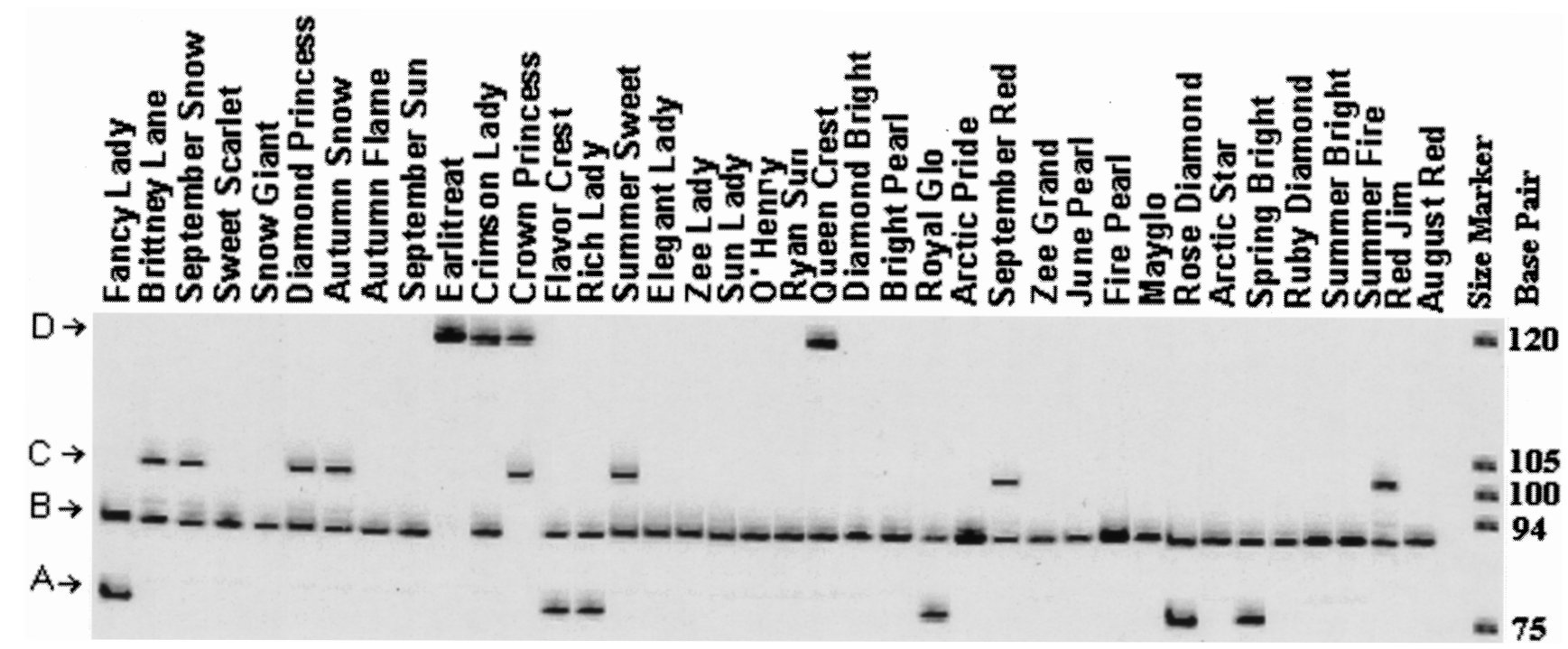

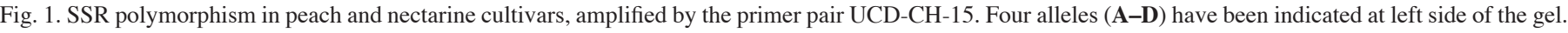
The IRD-labeled size marker (LI-COR) at right side was used for measuring allele size. All tested cultivars were put on the top of the gel picture.

LI-COR DNA sequencer. The bands were scored independently as being either present (1) or absent (0) in each genotype. Apparent polymorphisms appearing at the upper and lower limits of the band patterns were rejected due to the inconsistency of amplification and weakness of bands. Only bright, clearly, distinguishable bands were used in the genetic analysis.

Genetic similarity was estimated from 20 SSR and 49 SRAP polymorphic fragments. The PAUP* 4.0 b10 software package (Swofford, 2002) was used to generate a matrix of mean character differences and then to produce a dendrogram using the unweighted pair group method average (UPGMA) clustering.

\section{Results and Discussion}

The number of putative SSR alleles and their expected size in the 38 peach and nectarine cultivars are shown in Table 2. Of the SSR primer combinations, 16 produced amplification products in the tested cultivars; 10 were polymorphic in these cultivars. In total, 35 putative alleles were detected with an average of 2.2 alleles per locus. All SSR loci that amplified in this closely related set of the 38 peach and nectarine cultivars displayed between one to five putative alleles for each locus. One or two alleles per cultivar indicated the diploid nature of these cultivars. Figure 1 shows an example in which the DNA from 38 peach and nectarine cultivars in genus Prunus was amplified to display the allelic variation at SSR locus UCD-CH15. This locus distinguished 'Earlitreat' " and Crown Prince' from the rest of the cultivars due to their unique fingerprint. 'Earlitreat' indicated one homozygous allele D at 120 base pair while two alleles C and D are present in 'Crown Princess' at position 105 and 120 base pair. From the 17 primer pairs developed in sweet cherry, $13(76 \%)$ worked in peach and nectarine. Rare microsatellite alleles (allele present only in one cultivar) were found in 'Royal Glo' (2), 'Diamond Bright' (2), 'Earlitreat' (2) and 'Brittney Lane' (1).

The number of bands produced by the SRAP protocol was highly variable, ranging from 10 to 33 with an average of 21.8 per primer combination. Ten primer combinations resulted in 49 polymorphic fragments in these samples. SRAP markers generated unique fingerprints for 30 out of the 38 cultivars. The degree and nature of polymorphism revealed by SRAP primer combination Me4Em4 is depicted in Fig.2. This one primer combination was able to distinguish 'Brittney Lane', 'Flavor Crest', 'Rose Diamond', 'Arctic Star' and 'Summer Bright' from the rest of the cultivars by their unique fingerprints. Primer combination $\mathrm{Me} 4 \mathrm{Em} 4$ was shown to be highly polymorphic and generated nine polymorphic fragments while a minimum of four polymorphic markers were produced by the Me2Em19. The maximum number of four rare alleles was observed in 'Arctic Star' followed by three in 'Red Jim', and 'Flavor Crest'. Similarly, 'Earlitreat', 'Brittney Lane', 'Sweet Scarlet', 'Zee Grand', 'Spring Bright' and 'August Red' were identified by one cultivar-specific SRAP marker. We tried different primer combinations and we found that any combination, in which there was only one base difference in the sequences of the two primers did not produce any amplification and was excluded from the experiment. Thus, as noted by $\mathrm{Li}$ and Quiros (2001), the use of a two-primer combination is essential for successful amplification of SRAP bands.

Based on the 20 SSR and 49 SRAP polymorphic fragments, a similarity matrix was calculated according to (Sneath and Sokal, 1973). The relationship among the 38 peach and nectarine cultivars included in this study is represented by the UPGMA dendrogram (Fig. 3). In this dendrogram, nectarine cultivars are interspersed among peach cultivars. The four earliest-ripening nectarine cultivars, which start ripening in mid-May-Arctic Star, Mayglo, Royal Glo, and Rose Diamond - are the last cultivars to join the cluster. Most of the unique SSR and SRAP bands were observed in this group. 'Royal Glo' was close to 'May Glo' due the presence of 'May Glo' in its parentage. The close relationship of 'Rose Diamond' to this group was confirmed by tracing back its pedigree, which contains another early cultivar-May Grand - which is also a parent of 'May Glo'.

Another major group included yellow flesh, free stone peaches 'Snow Giant', 'Autumn Flame', 'Elegant Lady', 'Zee Lady', 'September Sun', 'O'Henry', and 'Ryan Sun'. All of these cultivars have 'O'Henry' as one of their parents. The presence of 'Summer Fire' nectarine in this group may be due to some mislabeling since the pomological data and pedigree for this cultivar does not match with this group. Most similar to each other are the two freestone late ripening peaches, 'O'Henry' and 'Ryan Sun', since 'Ryan Sun' is originated from 'O'Henry'. Sharing of maximum number of alleles within this group indicated a narrow genetic divergence. The presence of the late, yellow flesh peach 'Sun Lady' close 


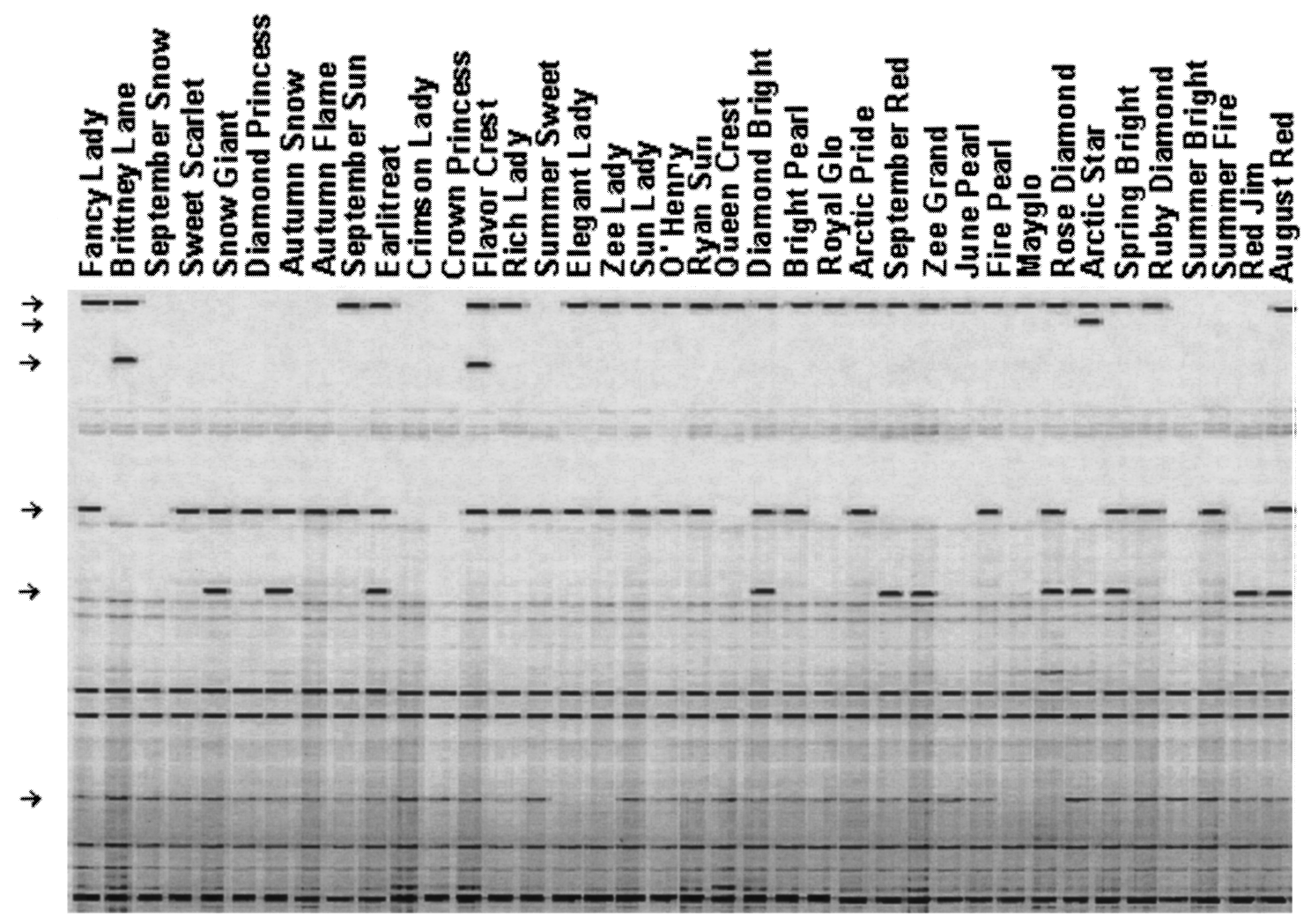

Fig. 2. SRAP fingerprint of 38 peach and nectarine cultivars generated by the primer combination Me4Em4 with polymorphic fragments indicated by arrows. This picture shows only the middle portion of the gel.

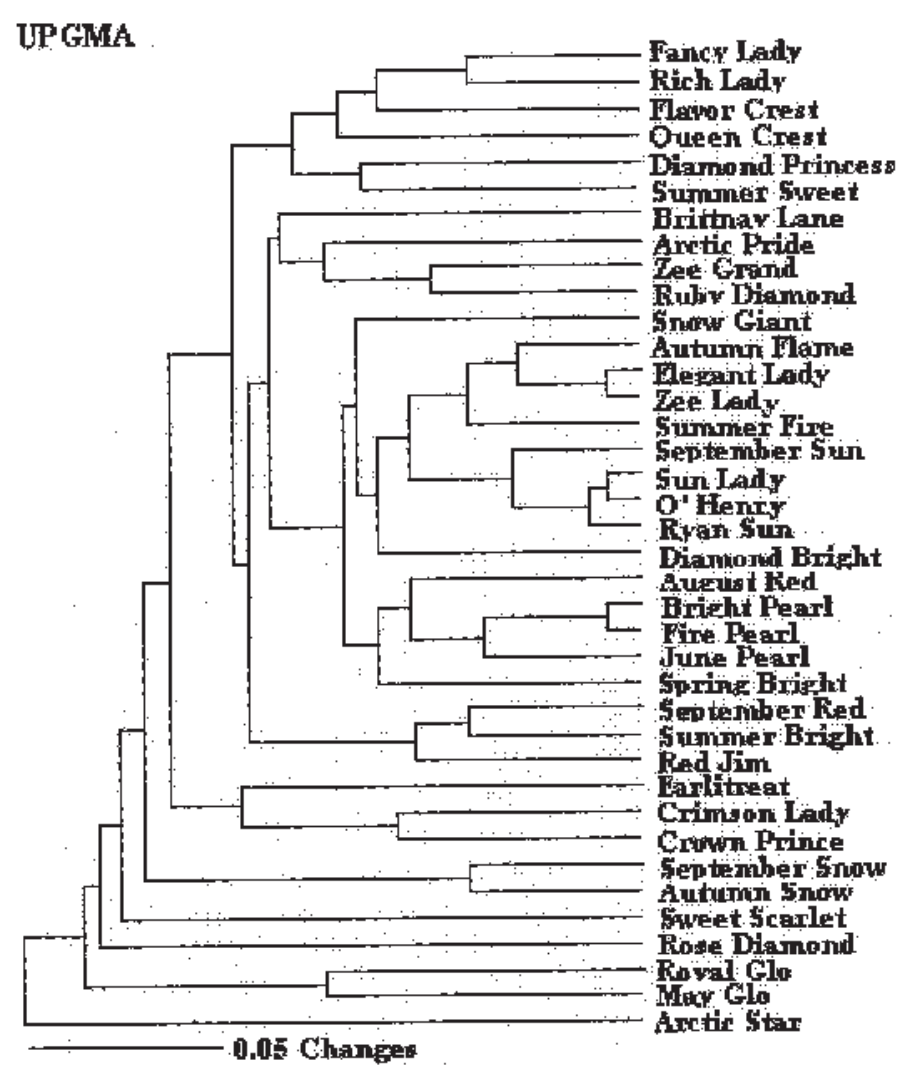

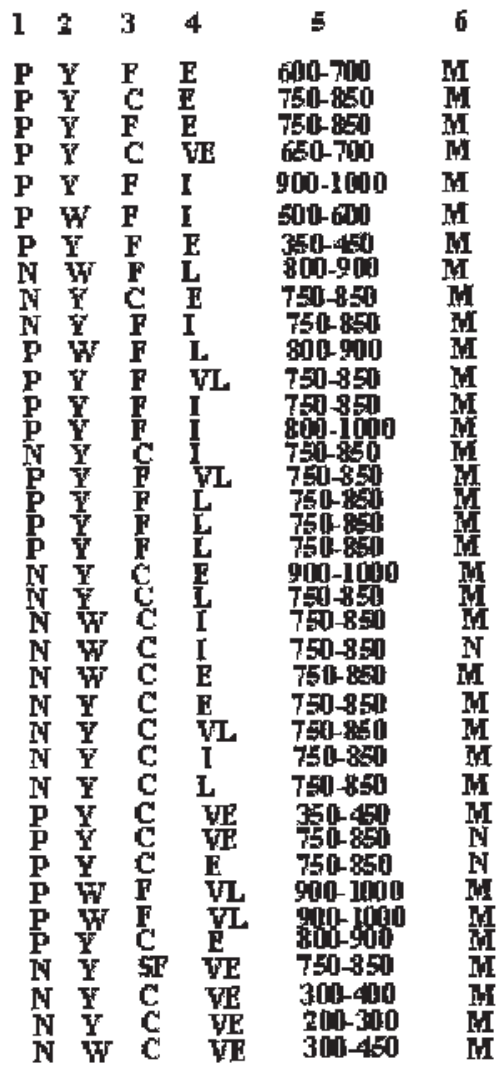

Fig. 3. Dendrogram of 38 peach and nectarine cultivars constructed from the matrix based on pairwise mean character differences. On right side pomological characters have been put for each cultivar. (1) Cultivar type: $\mathrm{P}=$ peach, $\mathrm{N}=$ nectarine; (2) flesh color: $\mathrm{Y}=$ yellow, $\mathrm{W}=$ white; (3) flesh type, $\mathrm{F}=$ freestone, $\mathrm{C}=$ clingstone, SF = semifreestone; (4) ripening date: VE = May, E = June, I = July, L = August, VL = September, based on ripening start date at Fresno Calif.; (5) chill hours requirement; (6) $\mathrm{M}=$ melting flesh, $\mathrm{N}=$ nonmelting flesh. 
to 'O'Henry' may be due to the presence of 'J.H. Hale' peach in the parentage of both of these cultivars. The two clingstone nectarines, 'Bright Pearl' and 'Fire Pearl', have the clingstone nectarine 'August Red' in their pedigree and hence are close to each other. Only one SRAP marker was able to distinguish the very closely related 'Bright Pearl' and 'Fire Pearl' nectarine. The close association of 'June Pearl' in this group with 'Fire Pearl' may be due to one common parent 'Bradcrim' in the development of these cultivars. The two nonmelting, early, clingstone peach 'Crown Princess' ('Red Diamond' x peach unknown selection) and Crimson Lady ('Red Diamond' $x$ 'Springcrest') $x$ unknown selection are close to each other. The close association of an early clingstone peach 'Earlitreat' ('Red Grand' x 'Desertgold') x Sweet Gem to 'Crown Princess' and 'Crimson Lady' may be due to 'Red Grand' as one parent in the development of 'Red Diamond'. 'Red Grand' was also in the parentage of the three clingstone nectarines 'September Red', 'Summer Bright' and 'Red Jim', which are close to each other. The two freestone, late-season white nectarines, 'September Snow' and 'Autumn Snow', are close to each other, but the molecular data could not confirm that 'Snow Giant' was in the parentage of 'Autumn Snow' [Zaiger 107ED101 (Snow Giant op)] x Zaiger 97GF518 (Snow Giant op)] since these two cultivars are present in separate groups, which are far from each other. The four yellow-flesh peaches in the early ripening season-Fancy Lady, Rich Lady, Flavor Crest, and Queen Crest-and the two mid-season peaches - 'Diamond Princess' and 'Summer Sweet' are close to each other. When the pedigrees of these cultivars were traced, it showed that 'Elberta' [Chinese Cling op x (Early Crawford ?)] was in the parentage of all of these cultivars. The three nectarines - 'Ruby Diamond', 'Zee Grand', and 'Arctic Pride' - have been developed from different crosses, but when their pedigrees were traced, it showed that 'Elberta' peach was present in the parentage of all these cultivars, accounting for their association in the dendrogram.

From these results, it appears that most of the peach cultivars we analyzed came from intercrossing a limited number of genotypes for a few generations as observed by Scorza et al.(1985). Similarly the predominance of selfing in peach (Miller et al.,1989) would lead toward homozygosity as the SSR analysis has confirmed. The average number of putative SSR alleles in our study was 2.2 which was lower than the 4.5 previously observed by Testolin et al. (2000) in a set of 50 peach cultivars with 26 SSR primer pairs and the 3.2 detected by 24 SSR primer pairs in 25 genotypes by Aranzana et al. (2002). The low number of alleles indicated in part the narrow genetic basis in this set of commercial peach and nectarine cultivars. Guilford et al. (1997) found that the number of alleles observed for SSRs in peach appeared to be relatively low (one to four) when compared with other species such as apple (one to nine). Isozyme analysis has resolved few polymorphisms among peach cultivars (Arulsekar etal., 1986; Byrne, 1990; Werner, 1992) although polymorphism have been more common among those clones from China or other countries (Mowrey et al., 1990; Werner, 1992) as compared to the commercially important melting flesh varieties of the United States. According to Ibanez et al. (1993) and Messeguer et al. (1987), the nonmelting types had more polymorphism than the United States fresh market melting type varieties. The results of isozyme studies have been confirmed by RAPD marker analysis of peach germplasm, that the peach germplasm from the United States is relatively homogeneous as compared to the germplasm collected from China and other parts of Asia (Warburton and Bliss, 1996).

Successful amplification in peach and nectarine of more than
$76 \%$ of primers developed in cherry, demonstrates the cross-transportability of these markers among Prunus species as has been shown in previous studies with microsatellites on genus Prunus (Cipriani et al., 1999; Downey and Iezzoni 2000; Hormaza, 2002; Martínez-Gómez et al., 2003; Sosinski et al., 2000). These results demonstrate that microsatellites are very powerful markers for synteny analysis in Prunus.

According to our results, SRAP protocol revealed more polymorphisms than SSR in a species with low variability such as the peach (Byrne, 1990). Of the cultivars analyzed, more than $85 \%$ had a unique SRAP fingerprint, which confirmed the high efficiency of this marker system for identifying genetic diversity in peach and nectarine. The number of markers generated by the SRAP method was almost the same as observed by Aranzana et al. (2001) in the analysis of 18 peach varieties with nine AFLP primer combinations, which resulted in 40 polymorphic marker, showing the low level of genetic diversity in peach.

In conclusion, SSR and SRAP molecular markers can be used for the grouping and identification of peach and nectarine cultivars as a complement to pomological studies. In addition, SRAP has been shown to be a quick, simple, and reproducible method for molecular analysis. Its potential in cultivar identification, gene mapping and developing specific molecular markers for different characters in different crops has already been established (Ahmad et al., 2001; Li and Quiros, 2001).

\section{Literature Cited}

Ahmad. R., G. Li, Z. Quresh, M.S. Swati, and C.F. Quiros. 2001. Genetic diversity of oilseed Brassica napus inbred lines based on SequenceRelatedAmplified Polymorphism and its relation to hybrid performance. Plant Breeding 120:411-415.

Aranzana, M.J., J. Garcia-Mas, J. Carbo, and P. Arus. 2002. Development and variability of microsatellite markers in peach. Plant Breeding. 121:87-92.

Aranzana, M.J., M.C. de Vicente, and P. Arus. 2001. Comparison of fruit and leaf DNA extracts for AFLP and SSR analysis in peach (Prunus persica (L.) Batsch. Acta Hort. 546:297-300.

Arulsekar, S., D.E. Parfitt, and D.E. Kester.1986. Comparison of isozyme variability in peach and almond cultivars. J. Hered. 77:272-274.

Byrne, D.H. 1990. Isozyme variability in four diploid stone fruits compared with other woody perennial plants. J. Hered. 81:68-71.

Cipriani, G., G. Lot., W.G. Huang., M.T. Marrazzo., E. Peterlunger, and R. Testolin. 1999. AC/GT and AG/CT microsatellite repeats in peach (Prunus persica): Isolation, characterization and cross-species amplification in Prunus. Theor. Appl. Genet. 99:65-72.

Doyle, J.J. and J.L. Doyle.1987. A rapid DNA isolation procedure for small quantities of fresh leaf tissue. Phytoch. Bul. 19:11-15.

Downey, S.L. and A.F. Iezzoni. 2000. Polymorphic DNA markers in black cherry (Prunus serotina) are identified using sequences from sweet cherry, peach, and sour cherry. J Amer. Soc. Hort. Sci. 125:76-80.

Ferriol. M., B. Pico, and F. Nuez. 2003. Genetic diversity of a germplasm collection of Cucurbita pepo using SRAP and AFLP markers. Theor. Appl. Genet.107: 271-282.

Fideghelli, C., G. Della Strada., F. Grassi, and G. Morico.1998. The peach industry in the world: Present situation and trend. Acta Hort. 465:29-40.

Guilford, P., S. Prakash, J.M. Zhu, E. Rikkernink, S. Gardiner, H. Bassett, and R. Forster. 1997. Microsatellite in Malus $\times$ domestica (apple). Abundance, polymorphism and cultivar identification. Theor. Appl. Genet. 94:245-249.

Hormaza, J.I. 2002. Molecular characterization and similarity relationships among apricot (Prunus armeniaca L.) genotypes using simple sequence repeat. Theor. Appl. Genet. 104:321-328.

Ibanez, M.A., M.A. di Renzo, and M.M.Poverene.1993. Isozyme diversity among and within peach groups: Freestone, clingstone and nectarines. Scientia Hort. 53:281-288. 
Li, G. and C.F. Quiros. 2001. Sequence-related amplified polymorphism (SRAP) a new marker system based on a simple, PCR reaction: Its application to mapping, and gene tagging in Brassica. Theor. Appl. Genet. 103:455-461.

Martínez-Gómez P., S. Arulsekar, D. Potter, and T.M. Gradziel. 2003. Relationships among peach, almond and related species as detected by simple sequence repeat (SSR) markers. J. Amer. Soc. Hort. Sci 128:667-671.

Miller, P.J., D.E. Parfitt, and S.A. Weinbaum. 1989. Outcrossing in peach. HortScience. 24:359-360.

Messeguer, R., P. Arus, and M. Carrera. 1987. Identification of peach cultivars with pollen isozymes. Scientia Hort. 31:107-117.

Mowrey, B.D., D.J. Werner, and D.H. Byrne. 1990. Inheritance of isocitrate dehydrogenase, malate dehydrogenase, and shikimate dehydrogenase in peach and peach $\mathrm{X}$ almond hybrids. J. Amer. Soc. Hort. Sci. 115:312-319.

Provan, J., W. Powell, and R. Waugh. 1996. Microsatellite analysis of relationships within cultivated potato (Solanum tubersum). Theor. Appl. Genet. 92:1078-1084.

Scorza, R., S.A. Mehlenbacher, and G.W. Lightner. 1985. Inbreeding and coancestry of freestone peach cultivars of the eastern United States and implications for peach germplasm improvement. J. Amer. Soc. Hort. Sci. 110:547-552.

Scorza, R., W.B. Sherman, and G.W. Lightner. 1988. Inbreeding and coancestry of low chill short fruit development period freestone peaches and nectarines produced by the University of Florida breeding program. Fruit Variety J. 42:79-85.

Sneath, P.H.A. and R.R. Sokal. 1973. Numerical taxonomy. W H Freeman, San Francisco.

Sosinski, B., M. Gannavarapu, L.D. Hager, E. Beck, G.J. King, C.D. Ryder, S. Rajapakse, W.V. Baird, R.E. Ballard, and A.G. Abbott. 2000. Characterization of microsatellite markers in peach [Prunus persica (L.) Batsch]. Theor. Appl. Genet. 101:421-428.

Struss, D., R. Ahmad, and S.M. Southwick. 2003. Analysis of sweet cherry cultivars (Prunus avium L.) using SSR and AFLP markers. J. Amer. Soc. Hort. Sci. 128:904-909.

Swofford, D.L. 2002. PAUP*. Phylogenetic analysis using parsimony (* and other methods). version 4. Sinauer Assoc., Sunderland, Mass.

Testolin, R., T. Marrazzo, G. Cipriani, R. Quarta, I. Verde, M.T. Dettori, M. Pancaldi, and S. Sansavini. 2000. Microsatellite DNA in peach (Prunus persica L. Batsch) and its use in fingerprinting and testing the genetic origin of cultivars. Genome 43:512-520.

Warburton, M.L. and F.A. Bliss. 1996. Genetic diversity in peach (Prunus persica $\mathrm{L}$. batch) revealed by randomly amplified polymorphic DNA (RAPD) markers and compared to inbreeding coefficient. J. Amer. Soc. Hort. Sci. 12:1012-1019.

Werner, D.J. 1992. Catalase polymorphism and inheritance in peach. HortScience 27:41-43. 